\title{
A DISPOSIÇÃO DOS RESÍDUOS SÓLIDOS NO PONTAL DO PARANAPANEMA
}

\section{THE SOLID WASTE DISPOSAL IN THE PONTAL DO PARANAPANEMA}

\author{
Lucas Prado Osco ${ }^{1}$; Marcos Norberto Boin ${ }^{2}$; Munir Jorge Felício ${ }^{1}$; Ana \\ Paula Marques Ramos ${ }^{1}$. \\ ${ }^{1}$ Universidade do Oeste Paulista - UNOESTE, , Presidente Prudente, SP. ${ }^{2}$ Universidade \\ Federal da Grande Dourados - UFGD, Dourados, MS. \\ E-mail: pradoosco@gmail.com
}

RESUMO - O presente trabalho tem por finalidade apresentar o levantamento regional em relação ao modo de disposição final dos resíduos sólidos no Pontal do Paranapanema (ou UGRHI-22), a partir de constatações e visitas in loco em todos os aterros atualmente em funcionamento. Para tanto, reuniram-se informações a partir de estudos relacionados ao gerenciamento e às normas geotécnicas para aterros em ficha síntese, onde a mesma foi aplicada durante as vistorias realizadas em cada local. Constatou-se que nenhum dos depósitos apresenta as condições adequadas conforme a lei vigente (12.305/2010), que obriga o encerramento de quaisquer destinos finais que não em um aterro sanitário. Isto posto, deve-se salientar que além de nenhum dos aterros presentes possuir as exigências mínimas para um aterro sanitário, os mesmos muitas vezes comportam-se como vazadouros ou lixões à céu aberto, com presença de animais, catadores, queimadas, recebimento de resíduos não autorizados e diversas outras infrações. Assim, conclui-se que a situação diverge daquela apresentada pelo órgão ambiental (neste caso, a CETESB), e que muitas dessas áreas encontram-se geotecnicamente impróprias para destinar os resíduos sólidos dos municípios regionais.

Palavras-chave: UGRHI-22; Resíduo Sólido; Degradação Ambiental.

Recebido em: 08/08/2015 Revisado em: 08/09/2015 Aprovado em: 23/09/2015
ABSTRACT - The present study aims to presente a regional survey regarding the disposal manner of solid waste in the Pontal do Paranapanema (or UGRHI-22) from observations and visits in loco in all the currently landfills in operation. Therefore, we gathered information from studies related to the management and geotechnical standards for landfills in a summary sheet, where it was applied during the surveys conducted at each site. It was found that none of the deposits has the right conditions, according to the current law (12.305/2010), which requires the termination of any destinations other than a sanitary landfill. That said, it should be noted that not only one of the present landfills have the minimum requirements for a sanitary landfill, and they often behave as dumps, with the presence of 
animals, scavengers, burned wastes, unauthorized waste and several other offenses. We conclude, therefore, that the situation differs from that presented by the environmental agency (in this case, the CETESB), and that many of these areas are geotechnically unfit for the destination of the solid waste of the municipalities on the region. Keywords: UGRHI-22; Solid Waste; Environmental Degradation. 


\section{INTRODUÇÃO}

Dentre às ameaças impostas ao meio natural, a disposição de resíduos sólidos em aterros ganhou espaços de destaque em meio as demais questões ambientais. Entende-se que a exacerbada produção de lixo resulte em uma série de consequências nocivas ao ambiente, sobretudo, quando armazenado de modo inadequado, degradando não somente o local onde se encontra depositado, como também sujeitando o seu entorno às mesmas sequelas. Embora um risco à saúde humana, esses depósitos irregulares também oferecem perigos aos recursos naturais, sobretudo à água e ao solo devido a produção de chorume.

A formação do chorume se inicia durante a deposição dos resíduos sólidos na área do aterro, onde ocorre a perda da água contida na matéria orgânica, percolando-a no solo e subsolo local (GIORDANO; FILHO; CARVALHO, 2011). A pluviosidade, por sua vez, aumenta o volume de liquido produzido, que ao infiltrar pela massa de resíduos mistura-se aos compostos dissolvidos por processos de decomposição biológica (SOUZA, 2005). Ressalta-se que em casos de poluições de águas subterrâneas, como em aquíferos, não há autodepuração, pois a atenuação da contaminação ocorre somente por diluição. Assim, por conta das altas concentrações de matéria orgânica, sais, amônia e metais pesados, a qualidade destas águas apresentam-se degradadas (PASCHOALATO, 2000).

A Política Nacional de Resíduos Sólidos (Lei 12305/10), determinou que todos os municípios destinassem seus resíduos sólidos para aterros sanitários a partir de agosto de 2014, encerrando a deposição em quaisquer outras áreas, tais como aterros em vala ou controlados, lixões, vazadouros, bota-foras, dentre outros. De tal modo, poderia se supor que hoje os municípios, ao menos, dariam início ao processo de implantação de áreas para aterros sanitários, entretanto não é o que se observa.

Há uma inegável negligência em cumprir tais exigências, e, por conta de tamanha situação, a disposição de resíduos remanesce em condições inadequadas. Porém, em meio aos debates políticos, econômicos, sociais e culturais, a capacidade do meio natural em suportar os impactos oriundos desses depósitos, em superfície ou sub-superfície, deve ser discutido. Com a finalidade de exemplificar a questão aludida, o presente trabalho optou por adotar a região do Pontal do Paranapanema, mais especificamente a 22a anidade de Gerenciamento de Recursos Hídricos (UGRHI22), abrangendo 26 municípios, sendo que apenas 22 desses possuem aterros de 
resíduos sólidos, em atividade, no seu território.

De acordo com o mais recente Índice de Qualidade de Aterros de Resíduos Sólidos (IQR), elaborado pela Companhia de Tecnologia de Saneamento Ambiental (2014), apenas 3 de 22 aterros encontram-se em situação irregular; enquanto os demais possuem condições adequadas. Nesse sentido, a questão central desse trabalho é compreender "Qual a real situação do aterros sanitários presentes na UGRHI-22?”. A hipótese levantada nessa discussão é que os aterros sanitários dessa bacia hidrográfica não se aparentam efetivamente como se tem divulgado nos resultados do estudo realizado pela CETESB. Para corroborar esta hipótese, objetivo deste trabalho consistiu em apresentar os problemas observados durante as vistorias in situ, nos anos de 2013 e 2014, nos 22 aterros de resíduos sólidos na região.

\section{METODOLOGIA}

Optou-se por utilizar a UGRHI-22 como área de estudo, em razão dessa unidade ser considerada como uma das bacias hidrográficas mais degradadas do Estado de São Paulo. Os resíduos sólidos, por sua vez, contribuem para o quadro, pois práticas de gerenciamento inadequado são conduzidas em todos os aterros regionais. Para corroborar essa afirmação, diversas vistorias e trabalhos de campo foram conduzidos ao longo dos anos de 2013 a 2014, onde foram percorridos cada um dos aterros de resíduos sólidos da UGRHI-22.

A averiguação em campo forneceu o material necessário para discutir e comparar o tratamento dado à essas localidades no decorrer do tempo da presente pesquisa, assim como identificar problemas, não somente no campo administrativo, mas em relação as condições geotécnicas a que esses depósitos se encontram. Porém, reforça-se que para a identificação das características físicas de cada aterro, tornou-se necessário elaborar, previamente, o estudo qualitativo no que diz respeito as propriedades naturais de seus ambientes. Assim, o levantamento da região forneceu os subsídios necessários para o diagnóstico dos locais de disposição final de resíduos sólidos. Essas informações do meio físico ofereceram suporte, mais especificamente, a adequação dessas áreas em relação às características geotécnicas locais.

Nesse contexto, fez-se uma adaptação ao Índice de Qualidade de Aterros de Resíduos Sólidos utilizado pela CETESB. Essa adaptação consiste na inserção de novos critérios embasados em estudos e pesquisas previamente elaborados por outros autores na área (ZUQUETE; GANDOLFI, 1981; FARIAS, 2002; LOUREIRO, 2005). As diretrizes desses trabalhos permitiram a complementação dos parâmetros necessários à adequação dos 
aterros de resíduos sólidos. A reunião dessas

informações foi sintetizada conforme durante as averiguações realizadas

nas apresentado na Tabela 1, de modo que se tornou possível preencher os parâmetros

Tabela 1. PARÂMETROS UTILIZADOS NA AVALIAÇÃO DE ATERROS DE RESÍDUOS SÓLIDOS

\begin{tabular}{|c|c|c|c|c|}
\hline Item & Aspecto & Critério Positivo & Critério Médio & Critério Negativo \\
\hline \multirow{14}{*}{ 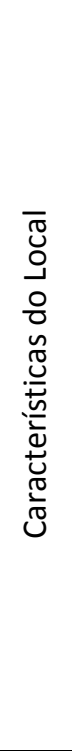 } & Proximidade de Corpos D'água* & $>200$ Metros & & $<200$ Metros \\
\hline & Proximidade de Núcleos Habitacionais* & $>500$ Metros & & $<500$ Metros \\
\hline & Proximidade de Aeródromos & > 20 Quilômetros & & < 20 Quilômetros \\
\hline & Declividade do Terreno & $>2 \mathrm{e}<8 \%$ & & $<2 \%$ e $>8 \%$ \\
\hline & Profundidade do Substrato Rochoso & $>15$ Metros & $<15$ e $>3$ Metros & $<3$ Metros \\
\hline & Profundidade do Lençol Freático & $>3$ Metros & $<3$ e $>1$ Metros & $<1$ Metro \\
\hline & Permeabilidade do Solo & Baixa & Média & Alta \\
\hline & Capacidade de Suporte do Solo & Adequada & & Inadequada \\
\hline & Material Para Recobrimento & Suficiente & & Insuficiente \\
\hline & Qualidade do Material de Recobrimento & Boa & & Ruim \\
\hline & Isolamento Físico* & Suficiente & & Insuficiente \\
\hline & Isolamento Visual* & Adequado & & Inadequado \\
\hline & Acesso à Frente de Cargas* & Adequado & & Inadequado \\
\hline & Distância de Rodovias & $>200$ Metros & & $<200$ Metros \\
\hline \multirow{10}{*}{ 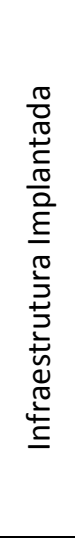 } & Cercamento da Área & Sim & & Não \\
\hline & Portaria ou Guarita & Sim & & Não \\
\hline & Vigilância & Sim & & Não \\
\hline & Trator de Esteiras ou Compatível & Permanente & Periodicamente & Inexistente \\
\hline & Drenagem de Gases & Suficiente & Insuficiente & Inexistente \\
\hline & Drenagem de Chorume & Suficiente & Insuficiente & Inexistente \\
\hline & Drenagem de Águas Pluviais* & Suficiente & Insuficiente & Inexistente \\
\hline & Impermeabilidade da Base do Aterro & Sim & & Não \\
\hline & Sistema de Tratamento de Chorume & Suficiente & Insuficiente & Inexistente \\
\hline & Monitoramento de Águas Subterrâneas* & Adequado & Inadequado & Inexistente \\
\hline \multirow{12}{*}{ 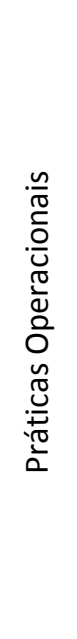 } & Dimensão das Valas* & Adequado & & Inadequado \\
\hline & Recobrimento dos Resíduos* & Adequado & & Inadequado \\
\hline & Ocorrência de Lixo Descoberto & Não & & Sim \\
\hline & Presença de Animais* & Não & & Sim \\
\hline & Queimada de Resíduos* & Não & & Sim \\
\hline & Presença de Moscas e Odores & Não & & Sim \\
\hline & Presença de Catadores* & Não & & Sim \\
\hline & Criação de Animais & Não & & Sim \\
\hline & Recebimento de Resíduos Industriais* & Não & & Sim \\
\hline & Recebimento de Resíduos Hospitalares* & Não & & Sim \\
\hline & Aproveitamento da Área* & Adequado & & Inadequado \\
\hline & Vida Útil do Aterro* & $>5$ Anos & $<5$ e $>2$ Anos & $<2$ Anos \\
\hline
\end{tabular}

Fonte: Adaptado de * Companhia de Tecnologia de Saneamento Ambiental (2014); FARIAS (2002); LOUREIRO (2005); Zuquete e Gandolfi (1991). 


\section{Localização da Área de Estudo}

A 22a Unidade de Gerenciamento de Recursos Hídricos (UGRHI-22), denominada como Bacia Hidrográfica do Pontal do Paranapanema, localiza-se no extremo oeste do Estado de São Paulo, na área confluência dos rios Paraná e Paranapanema, divisa com os Estados do Paraná e Mato Grosso do Sul. Situa-se entre as coordenadas 5051'57"W e $53^{\circ} 07^{\prime} 12^{\prime \prime} \mathrm{W}$ e $21^{\circ}-56^{\prime} 58^{\prime \prime} \mathrm{S}$ e $22^{\circ} 40^{\prime} 28^{\prime \prime} \mathrm{S}$, com uma área total $11.838 \mathrm{~km}^{2}$ (Figura 1).

Figura 1. Localização dos aterros de resíduos sólidos na UGRHI-22.

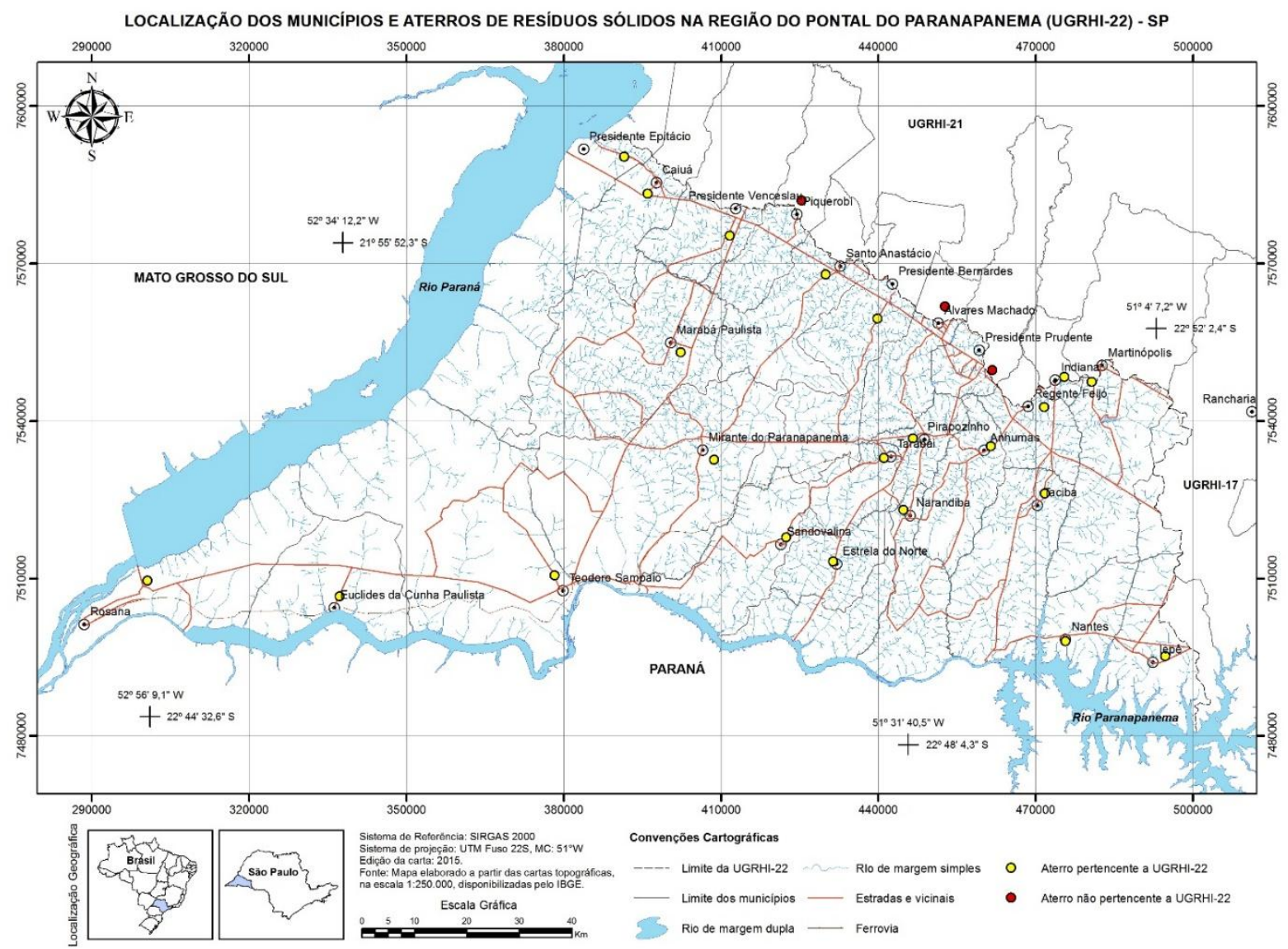

\section{RESULTADOS}

Em razão dos parâmetros apresentados na Tabela 1, nota-se que determinados critérios apresentam-se atrelados à subjetividade do avaliador, sobretudo, os que compõem o quadro técnico do órgão ambiental. Isto possibilita discussões sobre a real circunstância que se encontram os aterros de resíduos sólidos da
UGRHI-22. Cabe ressaltar que nenhum dos 22 aterros possuem sistemas de tratamento adequados a gás e chorume produzidos, pois consistem-se, em sua maioria, de aterros em vala (ou controlados), contando somente com um único aterro sanitário, localizado no município de Presidente Venceslau - SP, e um lixão (ou vazadouro) que se encontra no município de Pirapozinho - SP. 
Observações Realizadas nos Aterros Municipais de Resíduos Sólidos

O aterro municipal de Anhumas, apesar de apresentar no seu entorno um meio físico fragilizado, com elevados índices de declividade, solos rasos e proximidades à corpos d'água, encontra-se sobre um topo de colina plano. $O$ aterro possui certa adequabilidade em alguns dos aspectos, como o recobrimento diário do material, organização na escavação das valas, e a vigilância do mesmo. Para tanto, apesar de não ser um aterro sanitário, consiste-se num dos aterros mais bem cuidados da UGRHI-22, embora se situe próximo à uma unidade de alta vulnerabilidade (Figura 2).

Figura 2. Aterro Municipal de Resíduos Sólidos de Anhumas.

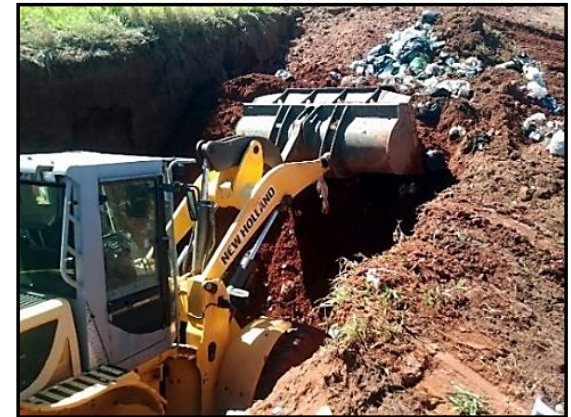

No município de Caiuá a localização do aterro se dá a uma distância do perímetro urbano decerca de 2,2 quilômetros, sobre um relevo ondulado, entre Colinas Amplas e Baixas, constituindo-se de Argissolo Vermelho-Amarelo, de profundidade média. Dentre os problemas encontrados, notou certa inconsistência nas valas, pois não existe um planejamento bem estruturado, sendo que os solos escavados revelaram resíduos sólidos depositados no passado. O local encontra-se devidamente cercado, com eucaliptos adultos em antigos espaços anteriormente usados na deposições de resíduos sólidos (Figura 3).

Figura 3. Aterro Municipal de Resíduos Sólidos de Caiuá.
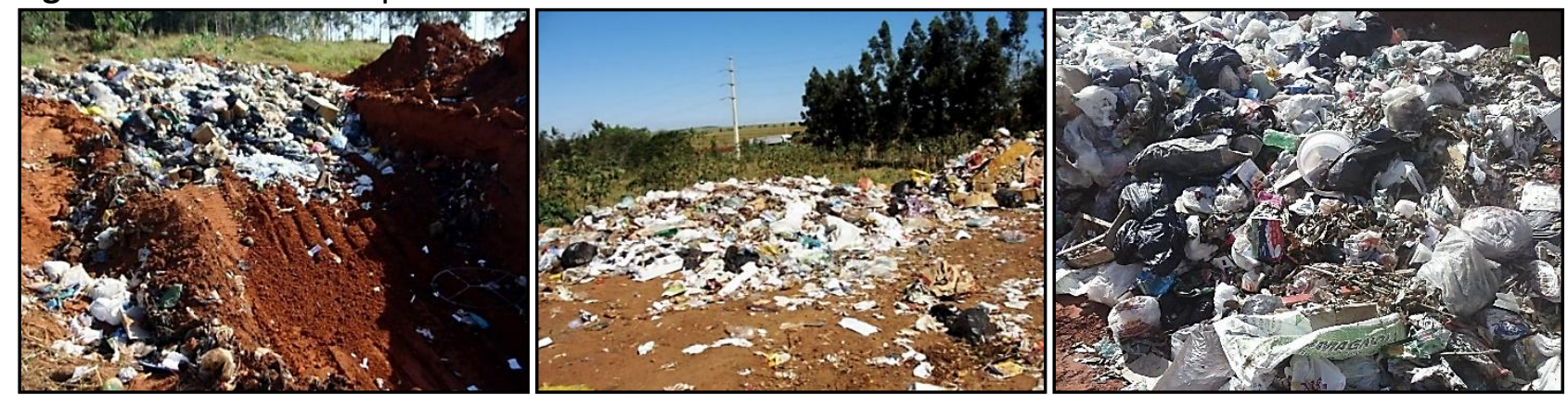
Outro aterro é o localizado em Estrela do Norte, o qual encontra-se sobre um relevo de Colinas Amplas, com predominância de Argissolo Vermelho-Amarelo. Este aterro oferece indícios de receber alguns dos cuidados com a infraestrutura e práticas operacionais. O local é cercado, contando com uma guarita para vigilância, recebendo somente resíduos autorizados. Há, no entorno, uma cortina de vegetação para amenizar odores característicos. Quanto a presença de animais, moscas e catadores, a área está dentro dos padrões exigidos. Um grave empecilho ao local ocorre devido à proximidade com o cemitério e com a cidade, a cerca de 400 metros (Figura 4).

Figura 4. Aterro Municipal de Resíduos Sólidos de Estrela do Norte.
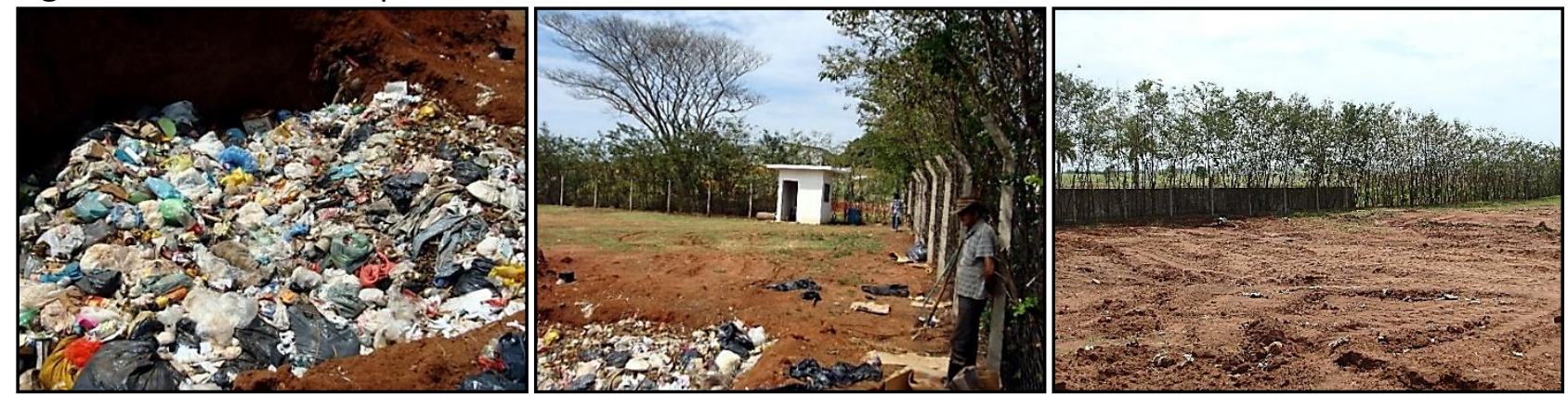

O aterro de resíduos sólidos em Euclides da Cunha Paulista encontra-se a cerca de 1,4 quilômetros do perímetro urbano, à margem da rodovia que interliga a cidade. Embora sobre área geotecnicamente favorável, o aterro ignora uma série de aspectos no que diz respeito à adequação das práticas operacionais. Apesar do local possuir condições naturais adequadas, os aspectos de infraestrutura e operação não são organizados, acarretando em adversidades. $\mathrm{O}$ recebimento inadequado de resíduos industriais, a falta de cobertura diária e sistemática do resíduo com solos, a inexistência de cerca viva, e a presença de animais, moscas e o odor fétido de podridão configuram a condição do local (Figura 5).

Figura 5. Aterro Municipal de Resíduos Sólidos de Euclides da Cunha Paulista.

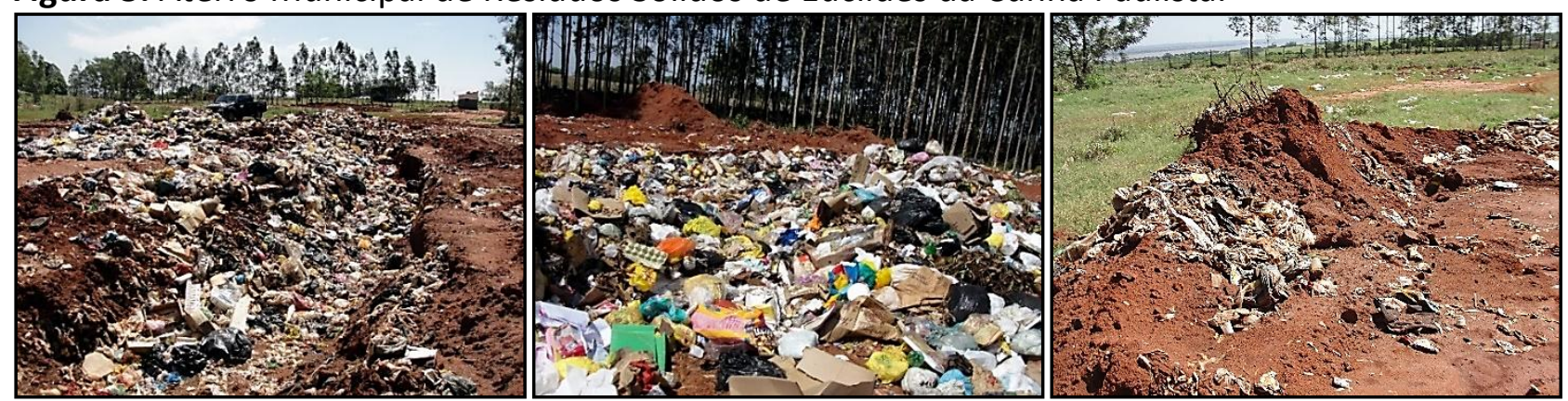


No município de lepê, os critérios voltados à geotécnica da área, como a profundidade do solo, substrato rochoso, lençol freático, permeabilidade, dentre outros, apresentam-se de modo satisfatório no local do aterro sanitário de resíduos sólidos. Porém, os resíduos se encontram a céu aberto, e o aterro possui a presença periódica de catadores e constante de animais. O local, apesar de não receber resíduos industriais ou hospitalares, tornouse depósito para as carcaças e queimadas de galhadas (Figura 6).

Figura 6. Aterro Municipal de Resíduos Sólidos de lepê.
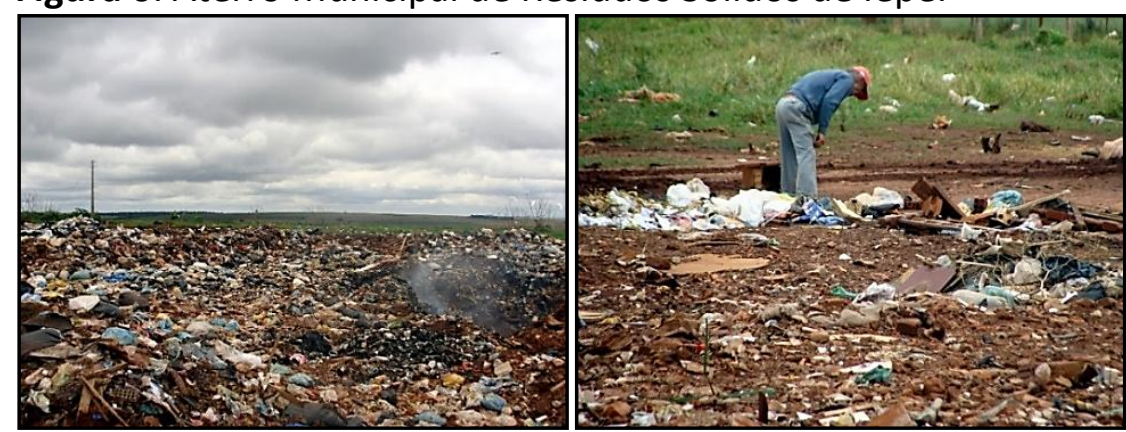

Outro município visitado foi o de Indiana, no qual o aterro municipal encontrase a menos de 1 quilômetro da cidade, numa estrada de fácil acesso na zona rural. Os solos são compostos predominantemente por Argissolos Vermelho-Amarelos, com baixas profundidades. A elevada declividade do relevo ao entorno, bem como a proximidade do recurso hídrico contribuem para a irregularidade da área. O local, ainda, encontra-se praticamente esgotado, contando com a presença de animais, catadores e recebimento de resíduos industriais e potencialmente perigosos (herbicidas e pesticidas). O galpão, onde costumavam armazenar resíduos da logística reversa, como por exemplo os pneus, foi incendiado por razões desconhecidas (Figura 7).

Figura 7. Aterro Municipal de Resíduos Sólidos de Indiana.

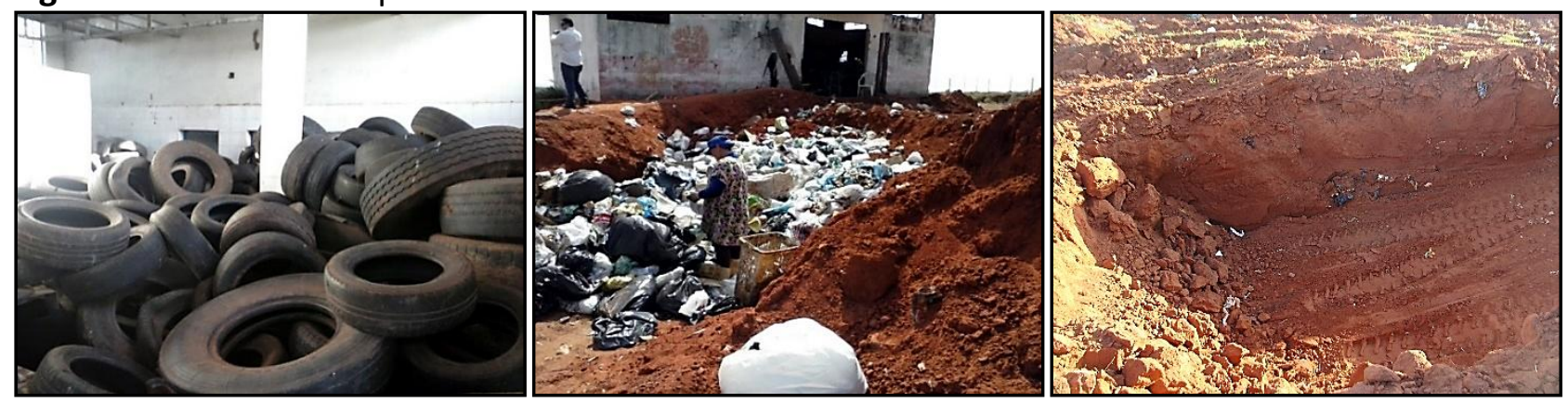


A área ocupada pelo aterro municipal de Marabá Paulista apresenta uma série de problemas na disposição dos resíduos, pois apesar de se encontrar sobre um solo raso (Argissolo Vermelho-Amarelo) e certamente fragilizado devido às condições locais, o mal aproveitamento da área com relação ao dimensionamento das valas (por sua baixíssima profundidade com cerca de 80 centímetros), compromete a vida útil do aterro. O local situa-se sobre relevo medianamente ondulado, com índices de declividade aceitáveis, distante de recursos hídricos. No que se refere aos aspectos operacionais e de infraestrutura, o aterro apresenta notável simplicidade, pois possui uma pequena cerca de arame liso no entorno, não existindo medidas de controle de entrada de pessoas. O resíduo apresentou fortes odores, sugerindo a falta de recobrimento por um longo período de dias (Figura 8).

Figura 8. Aterro Municipal de Resíduos Sólidos de Marabá Paulista.

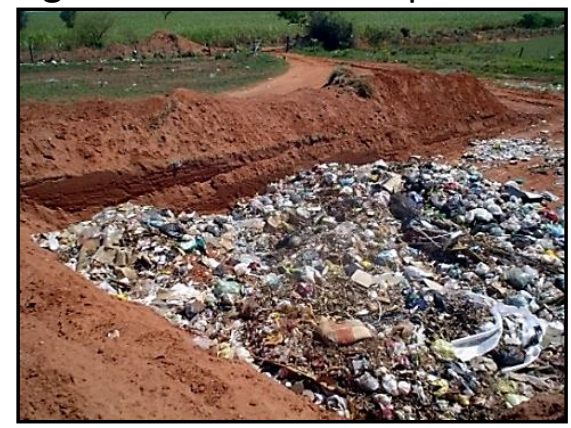

Em Martinópolis, notou-se que o aterro revelou zonas de solos profundos localmente e mais rasos conforme se distanciava de seu setor mais elevado, de relevo suave ondulado a ondulado. Essa área, contudo, encontra-se próxima ao recurso hídrico, em distância razoavelmente segura (460 metros), porém sobre uma cabeceira de drenagem. $\mathrm{O}$ aterro se destaca por aparentar alguns dos aspectos adequados, com a cooperativa local onde é realizada a separação dos resíduos, sendo autossuficiente em maquinário. Todavia, parte desses resíduos permaneciam em superfície, sendo pouco recobertos, e observou-se a presença de animais e desorganização com a abertura de valas. A cortina de vegetação é escassa, contornando apenas a entrada, acompanhando a frente de acesso, que limita a cerca do local somente por uma pequena porção (Figura 9). 
Figura 9. Aterro Municipal de Resíduos Sólidos de Martinópolis.
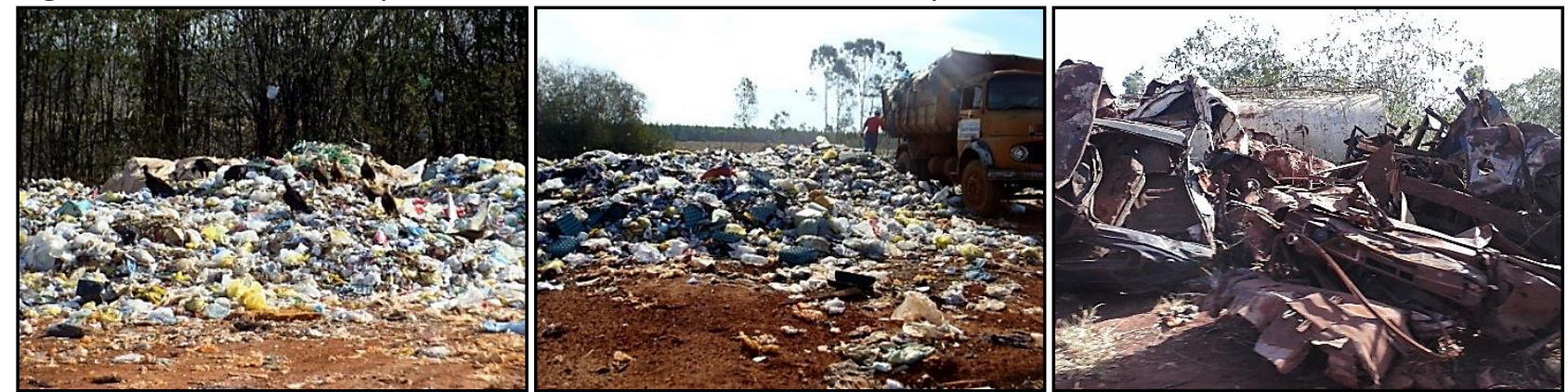

A situação do aterro de resíduos sólidos em Mirante do Paranapanema é semelhante aos supracitados. Apresenta solos medianamente profundos e relevo ondulado, de Colinas Amplas, situando-se em topo de colina, afastado do corpo d'água mais próximo, o aterro é cercado, deficientemente, por alambrados. Existe a presença de catadores, poucos animais e de resíduos sólidos não autorizados, como industriais e hospitalares. A largura das valas, bem como a extensão da área, são boas, o que confere ao aterro um maior prazo de vida útil (Figura 10).

Figura 10. Aterro Municipal de Resíduos Sólidos de Mirante do Paranapanema.
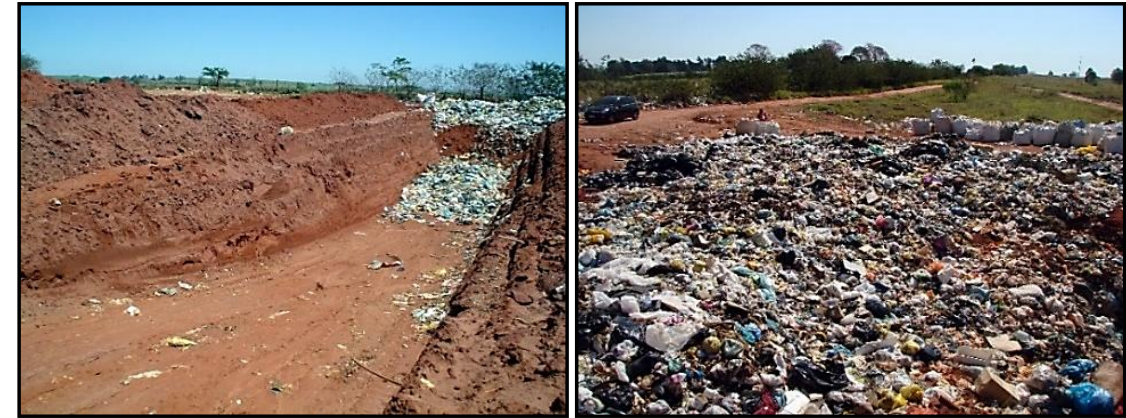

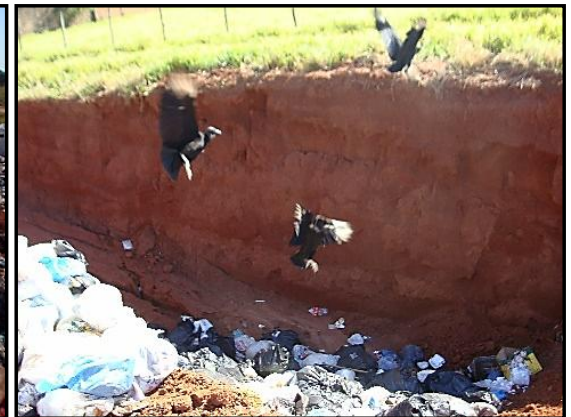

Em Nantes, o aterro situa-se próximo da malha urbana e extremamente próximo a um corpo d'água, acompanhado pela estação de tratamento de efluentes. Assim como em lepê, constatou-se a presença de animais (vivos e mortos) no local. A profundidade do lençol freático aparenta não ser baixa. 0 aterro se encontra sobre Nitossolo Vermelho, em Colinas Baixas, com topografia suavemente ondulada a plana. Essa área, apesar de pequena em comparação as demais, aparenta certa desorganização no que diz respeito a abertura de valas e recobrimento dos resíduos, recebendo material não autorizado, como carcaças dos animais mortos e ossadas de gado (Figura 11). 
Figura 11. Aterro Municipal de Resíduos Sólidos de Nantes.
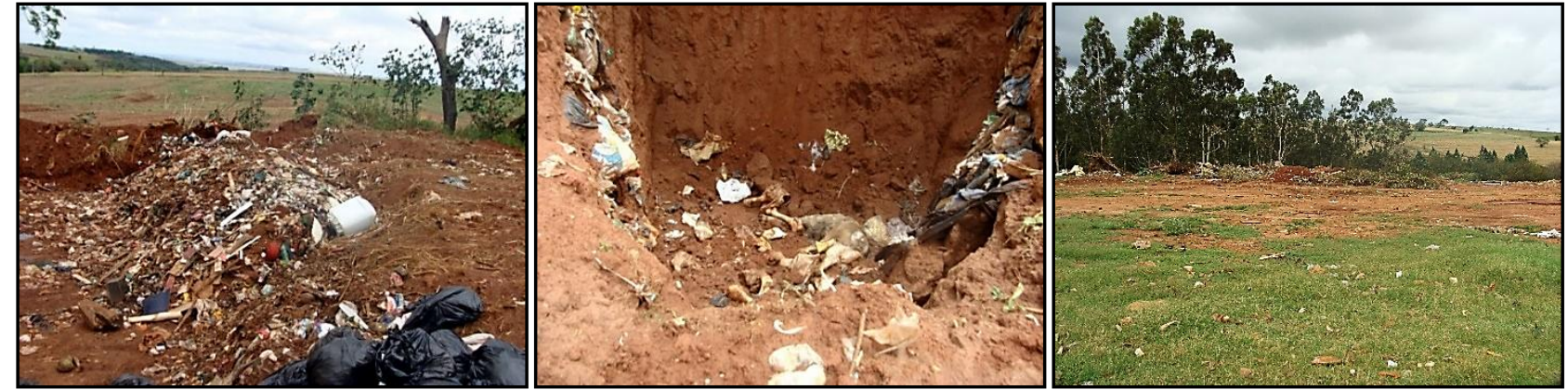

No aterro municipal de Narandiba, notou-se boas condições geotécnicas, como um profundo Latossolo Vermelho, de relevo plano e características adequadas. Desprovido de catadores, o aterro é recoberto com mais frequência que os demais aterros, refletindo na redução da presença de animais. Apesar disso, em relação ao cercamento local, o aterro requer uma cortina de vegetação no entorno, de modo a reduzir a intensidade dos ventos, isolar visualmente o local e amenizar o odor produzido. Outro fator é a sua localização ao lado da rodovia, quando deveria estar á no mínimo 200 metros de distância (Figura 12).

Figura 12. Aterro Municipal de Resíduos Sólidos de Narandiba.
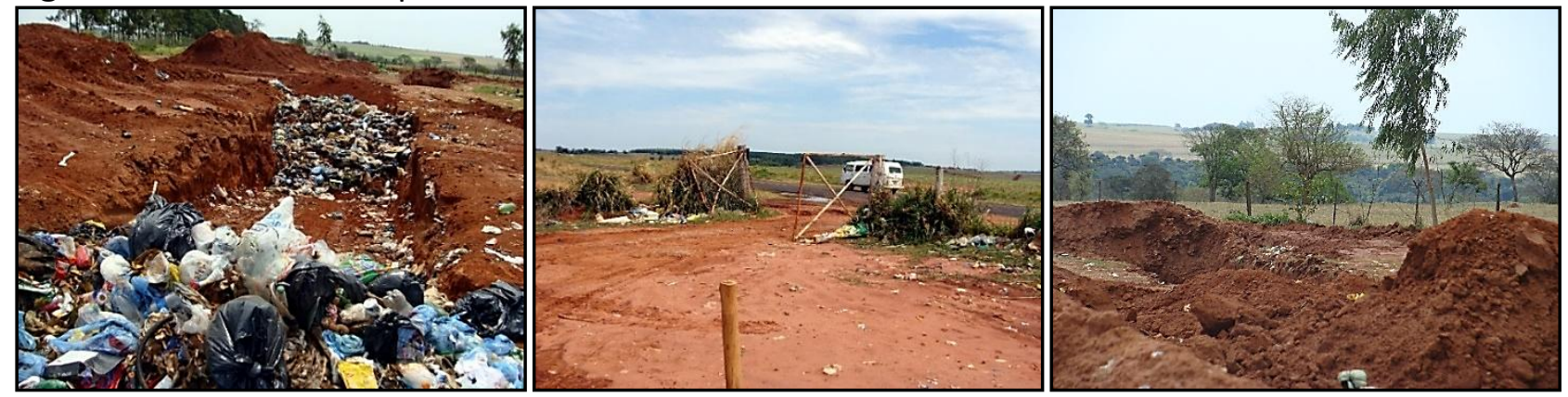

Em Pirapozinho, por apresentar índices de vulnerabilidade relativamente elevados, o depósito sujeita-se à uma série de implicações naturais, como a baixa profundidade dos solos, a acentuada declividade em setores muito próximos, e a presença de uma nascente na área. Todavia sua irregularidade não se dá somente pelas características naturais, mas também por deficiências na infraestrutura e nas práticas operacionais. O recobrimento dos resíduos é eventual, deixando a maior parte do tempo os resíduos exposta a céu aberto. Existe a presença ininterrupta de catadores, crianças, animais (e a criação de porcos) e de indivíduos que adentram ao local de forma não autorizada, pois não existe nenhuma forma de cercamento ou vigilância no local (Figura 13). 
Figura 13. Aterro Municipal de Resíduos Sólidos de Pirapozinho.
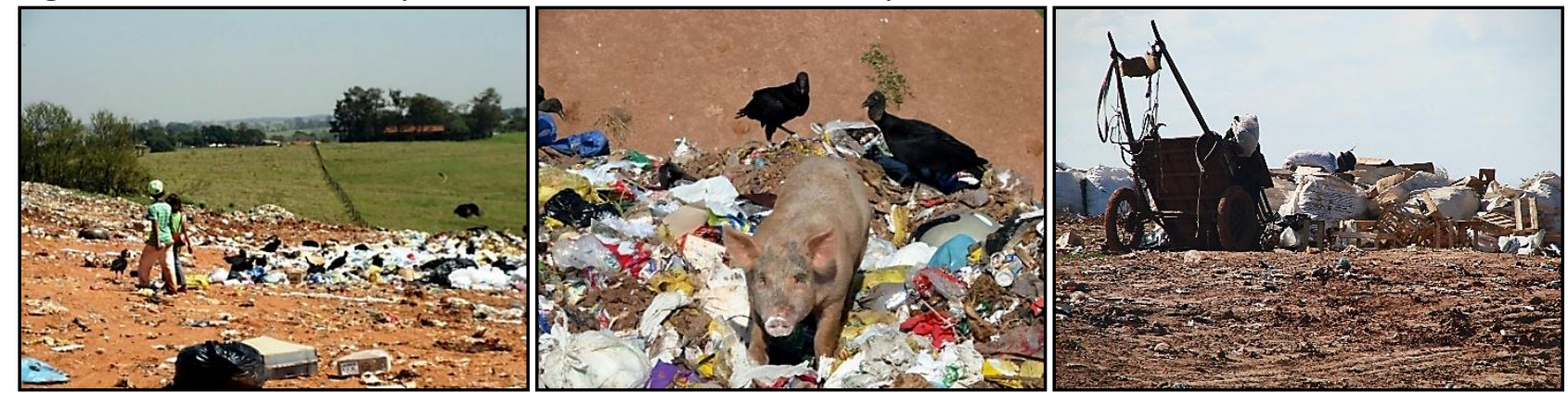

O aterro municipal de Presidente Bernardes encontra-se sobre uma área vulnerável em relação a proximidade com o corpo hídrico. Ainda que esteja sobre um topo, a expansão do aterro ocorreu em direção a nascente e ao córrego mais próximo, onde as vegetações nativas foram desmatadas para essa finalidade. O relevo ondulado, a baixa profundidade do Argissolo Vermelho-Amarelo encontrado, junto à presença de um lençol freático na meia encosta, contribuem para a inadequabilidade do local. Os resíduos sólidos são depositados diretamente no lençol d'água (freático), contaminando o recurso hídrico. O aterro possui um galpão destinado à separação de resíduos, recobertos diariamente com maquinário correto. Ainda assim, não atende a infraestrutura necessária e, em face disso, a contaminação do recurso hídrico adjacente é incontestável (Figura 14).

Figura 14. Aterro Municipal de Resíduos Sólidos de Presidente Bernardes.
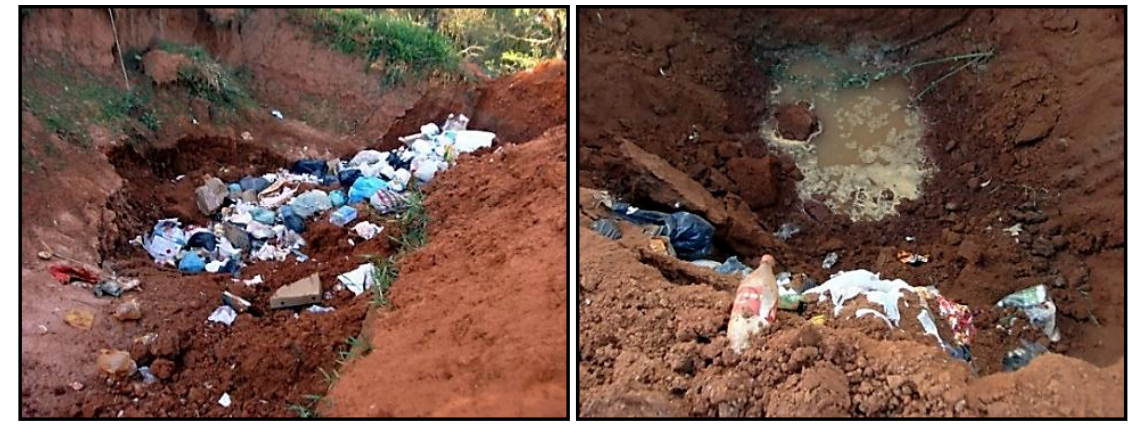

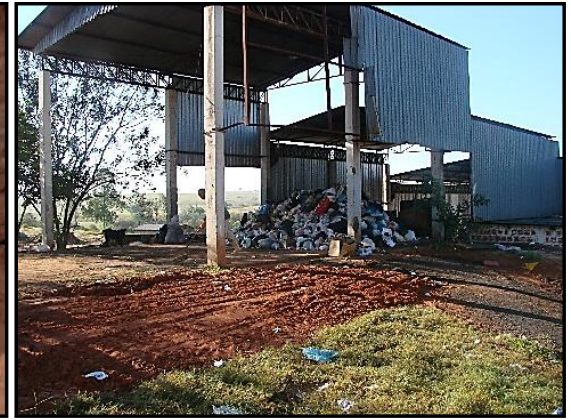

O aterro de Presidente Epitácio situase em uma localidade ambígua, onde embora concentre Latossolos Vemelho-Amarelos, em relevo pouco acidentado e de baixos graus de dissecação, o local é diferenciado devido à presença dos terraços aluviais. Ainda que encontrem-se à cerca de 500 metros, esses terraços indicam processos neotectônicos que possibilitaram a ocorrência de setores com maior vulnerabilidade, permitindo com que o lençol freático se concentrasse em áreas próximas da superfície. O aterro, ainda, apresenta práticas operacionais errôneas, embora conte com a presença de 
cooperativados durante a separação dos resíduos sólidos recebidos. Não obstante, práticas inadequadas como a queimada de resíduos e o mal planejamento das valas comprometem a área (Figura 15).

Figura 15. Aterro Municipal de Resíduos Sólidos de Presidente Epitácio.

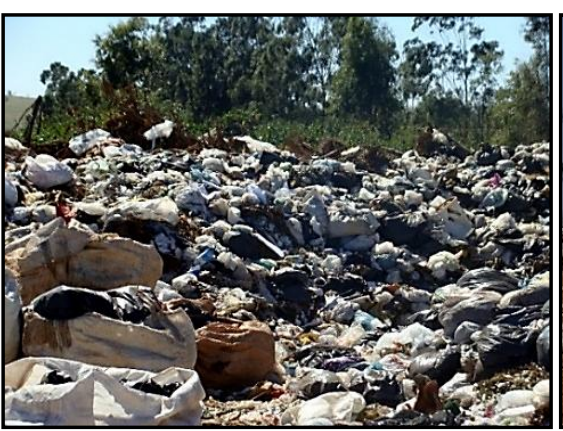

O único aterro de resíduos sólidos na UGRHI-22 com a infraestrutura necessária de um aterro sanitário "senso strito" situa-se no município de Presidente Venceslau. Contudo, ao verificar as condições de operação do aterro percebeu-se que rede coletora de chorume, pela má drenagem ou inexistente tratamento da lagoa, conteve o contaminante sobre suas mantas, permitindo acumulação e ascensão do líquido que extravasa a trincheira e adentra os drenos de gazes, tornando 0 aterro totalmente ineficiente em preservar a qualidade dos recursos naturais na área e no entorno. Isso, somado à presença de animais, catadores, queimadas e outras ocorrências, garante ao aterro as péssimas condições. A contaminação do local apresenta-se evidente, uma vez que o chorume armazenado transborda da lagoa, dirigindose à porções mais declivosas. A área está sobre um setor relativamente plano, de Argissolo Vermelho-Amarelo pouco profundo, agravando seus problemas (Figura 16).

Figura 16. Aterro Municipal de Resíduos Sólidos de Presidente Venceslau.
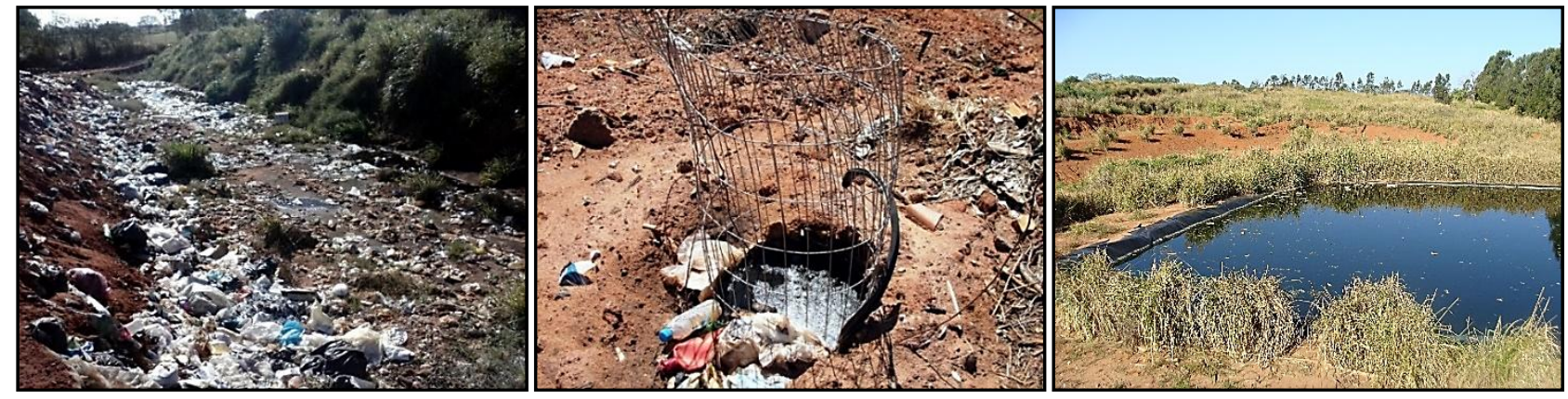
No município de Regente Feijó o aterro de resíduos sólidos apresenta em seus arredores condiçoes extremamente fragilizadas, pois observou a ocorrência de Argissolo Vermelho-Amarelo, relevo ondulado e proximidade muito grande ao corpo d'água (110 metros). O recobrimento dos resíduos sólidos ocorre de maneira irregular, o que contribui para o surgimento de animais e moscas, além da proliferação de vetores. O aterro possui uma acomodação voltada à separação diária dos resíduos. Constatou-se o recebimento de resíduos industriais e perigosos, comprometendo com a adequação do local (Figura 17).

Figura 17. Aterro Municipal de Resíduos Sólidos de Regente Feijó.
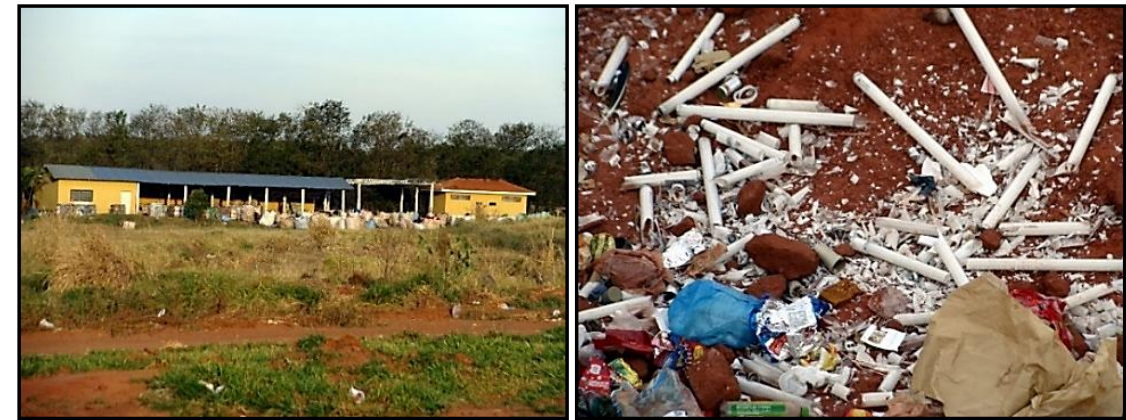

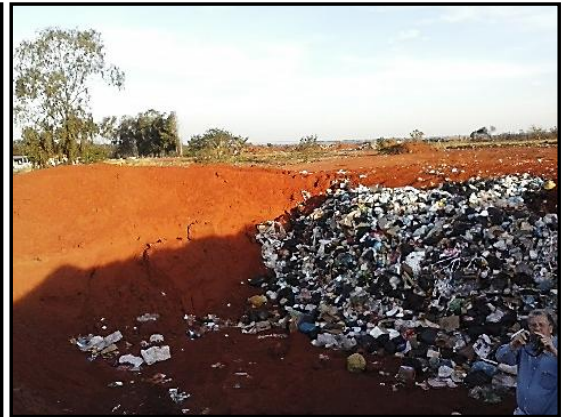

O município de Rosana, por sua vez, destina os resíduos ao seu distrito, Primavera. No local, os Latossolos VermelhoAmarelos apresentam profundidades expressivas, sendo bem desenvolvidos, sobre um relevo de Colinas Baixas. Dentre as práticas operacionais errôneas dadas, o aterro se destaca por uma exacerbada concentração de resíduos em superfície, sujeitando-os ao recobrimento das valas apenas após a separação do material reciclável, realizados por catadores. Observou-se a remoção dos fragmentos de vegetação nativa para a expansão da área atual, enquanto a anterior (e esgotada) permanece abandonada, sem práticas de recuperação ou remediação. O montante de resíduos sólidos é o suficiente para impressionar qualquer um que adentre a área (Figura 18). 
Figura 18. Aterro Municipal de Resíduos Sólidos de Rosana.

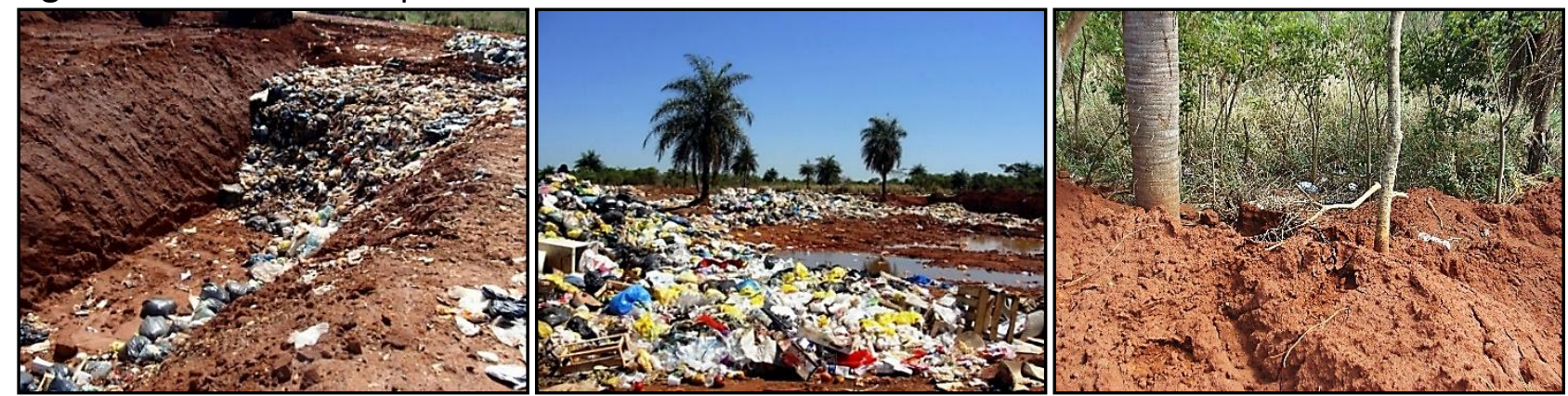

No município de Sandovalina, o aterro de resíduos sólidos permanece a pouco mais que 1,5 quilômetros da cidade, dividindo espaço com fragmentos florestais expressivos que margeia o ribeirão Taquaruçu. Observouse o descaso com a antiga área, onde $\mathrm{o}$ plantio de espécies nativas não recebera o cuidado adequado. Encontra-se, porém, devidamente cercado (embora não possua a cortina de vegetação) e sem queimas de resíduos. Recebe, entretanto, material industrial, comprometendo com a adequação do aterro (Figura 19).

Figura 19. Aterro Municipal de Resíduos Sólidos de Sandovalina.
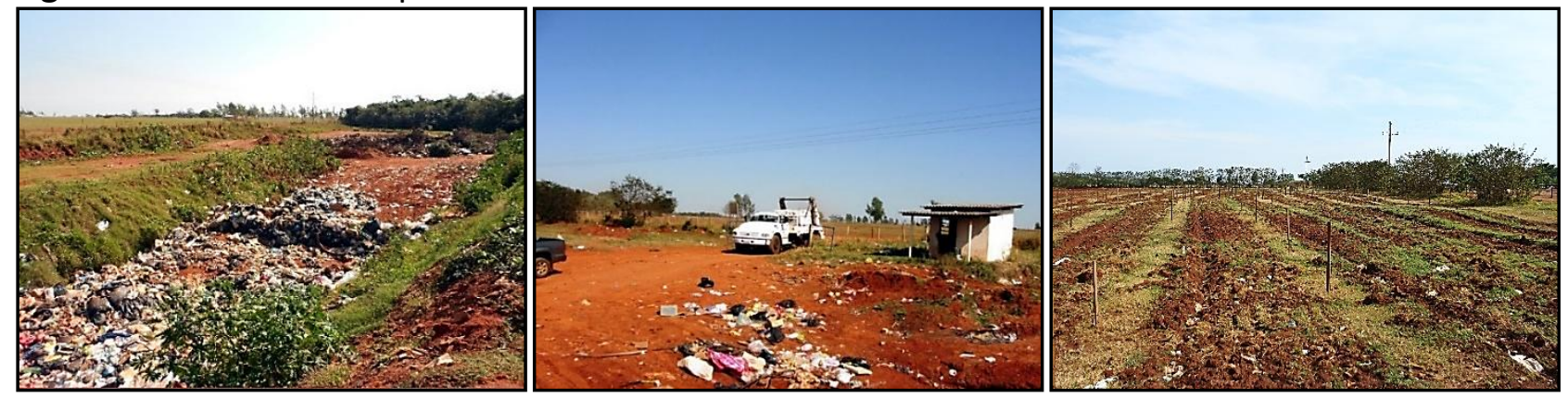

Em Santo Anastácio, o aterro encontra-se em relevo plano, sobre um divisor de água, com solos pouco espessos (Argissolo Vermelho-Amarelo), evidenciado na abertura das valas, onde é possível observar que há a escavação do maciço rochoso para a disposição dos resíduos em seu interior. As valas onde se encontram os resíduos não apresentam infraestrutura condizente com este tipo do empreendimento $\mathrm{e}$ os solos não tem capacidade de atenuação do contaminante porque são retirados para dispor os resíduos diretamente no maciço. As valas, por possuírem expressivas dimensões (em comprimento) demoram para serem preenchidas, proporcionando ao material descartado maiores períodos na superfície, atraindo animais e permitindo a proliferação de vetores. O local, apesar de cercado, não 
apresenta quaisquer outros aspectos de

infraestrutura (Figura 20).

Figura 20. Aterro Municipal de Resíduos Sólidos de Santo Anastácio.
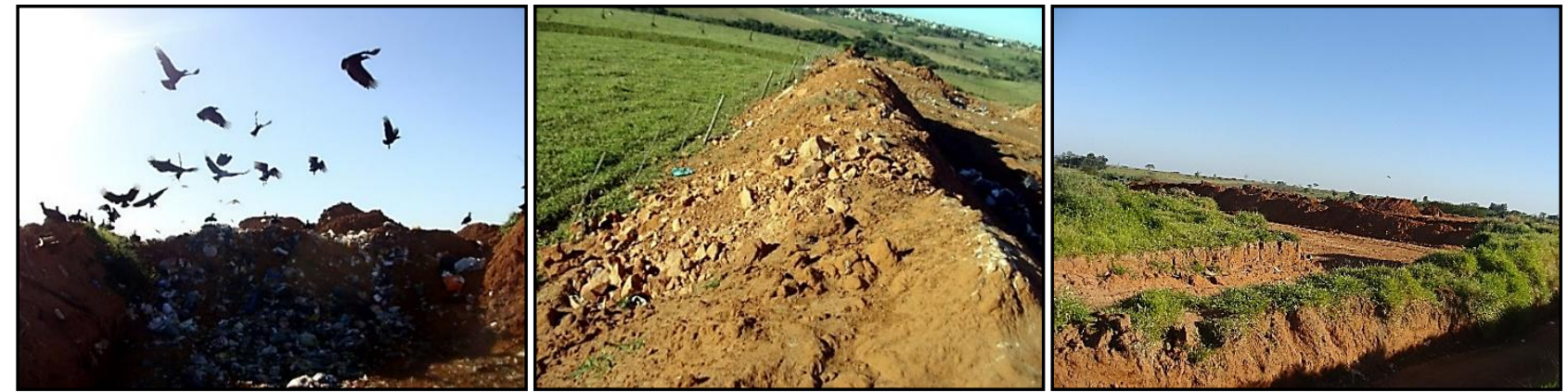

O aterro municipal de Taciba situa-se em área extremamente fragilizada, próxima a cabeceira de drenagem, protegida somente por vegetação ciliar. O relevo ao entorno revela setores declivosos, principalmente quando próximos ao curso d'água adjacente, enquanto o solo, classificado como Argissolo Vermelho-Amarelo, possui pequena profundidade. $O$ aterro apresenta pouco controle em relação ao contaminante e, relativo a infraestrutura, o local possui um galpão onde se realiza a separação dos resíduos. Não há cercas na área, e a presença de animais, moscas, e odor forte consistemse em alguns dos problemas observados (Figura 21).

Figura 21. Aterro Municipal de Resíduos Sólidos de Taciba.

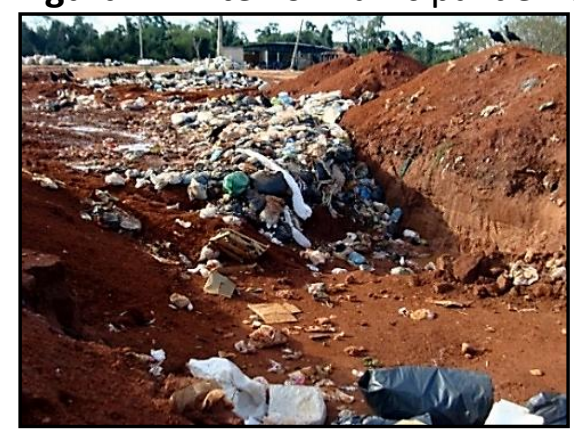

$\mathrm{O}$ aterro municipal de Tarabai, por sua vez, encontra-se sobre um relevo de Colinas Amplas. O aterro é possui Argissolo Vermelho-Amarelo, de boa profundidade. Dentre os problemas destaca-se a desconsideração com a vasta maioria dos parâmetros mínimos de adequabilidade, uma vez que foi constatado a presença (e criação) de animais, queimadas de resíduos hospitalares, depósitos de dejetos humanos e ausência de um recobrimento periódico de 
resíduos, construindo com a proliferação de

vetores (Figura 22).

Figura 22. Aterro Municipal de Resíduos Sólidos de Tarabai.
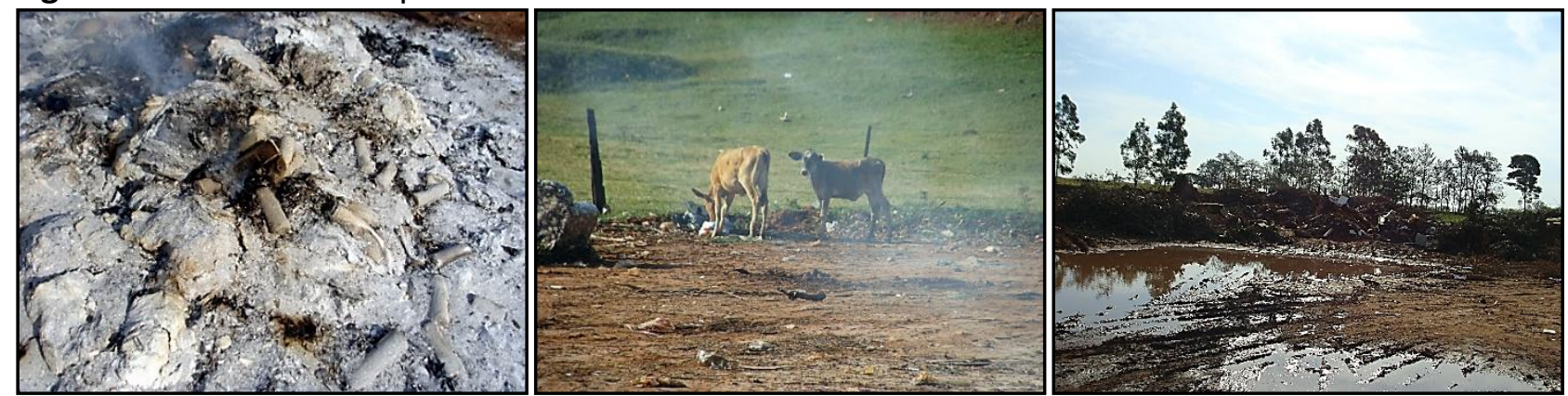

A área ocupada pelo aterro de Teodoro Sampaio destaca-se em razão de sua vasta extensão territorial, com Latossolos Vermelho-Amarelos, em Colinas Baixas, próxima a uma mata nativa em estágio de regeneração. A área mais antiga do local encontra-se esgotada, embora traços na aproveitamento em relação a abertura de valas. Não existem sistemas de separação dos resíduos sólidos, havendo uma constante presença dos trabalhadores, responsáveis por movimentarem solos no aterro, comprimirem o material descartado e recobrirem as valas (Figura 23).

superfície sugiram o seu mau

Figura 23. Aterro Municipal de Resíduos Sólidos de Teodoro Sampaio.

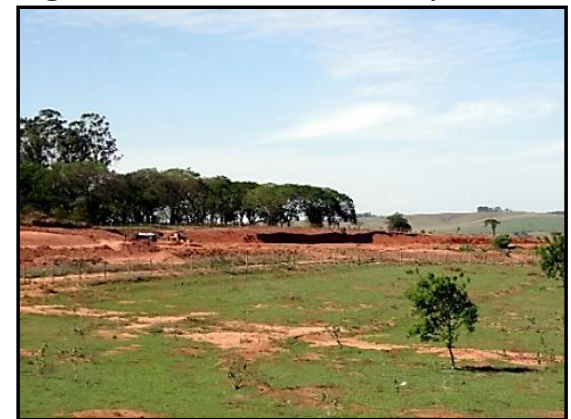

\section{DISCUSSÃO}

Diante

das

constatações

apresentadas, confirma-se o descaso, em praticamente, todas essas áreas de destinação final, sujeitas a graves problemas de contaminação dos solos, e, eventualmente dos recursos hídricos,
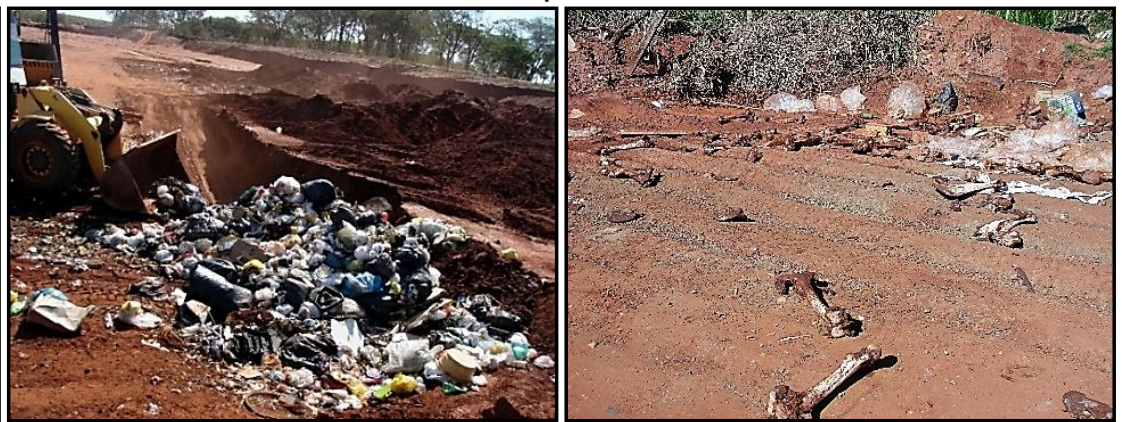

superficiais e subterrâneos. O levantamento e as averiguações em campo a todas essas localidades permitiu o diagnóstico da real condição que esses aterros se encontram. Assim, para sintetizar as informações obtidas, fez-se a separação das condições geotécnicas, das práticas de operação ou gerenciamento do local e das recomendações 
quanto à adequação dos depósitos (Tabela 2).

A proximidade dos aterros aos núcleos habitacionais implica um risco à população. Contudo, a abertura de novas e maiores áreas para aterros e a expansão das existentes, acaba por condenar o local, contaminando os recursos naturais existentes, caso não sejam implementados com técnica e operação adequada. Deve-se, portanto, incentivar práticas voltadas a recuperação das áreas, cumprindo a Lei e o dever exigido às suas adequações.

Tabela 2. Aterros de Resíduos Sólidos (Ugrhi-22) e Respectivas Condições

\begin{tabular}{|c|c|c|c|c|}
\hline Município & IQR (CETESB, 2014) & $\begin{array}{c}\text { Geotecnia } \\
*\end{array}$ & $\begin{array}{c}\text { Gerenciament } \\
\text { o* }^{*} \\
\end{array}$ & Recomendação ao Local \\
\hline Anhumas & 8,4 & $8 / 13$ & $12 / 22$ & Encerramento da Área \\
\hline Caiuá & 7,5 & $10 / 13$ & $7 / 22$ & $\begin{array}{l}\text { Implantação de Aterro } \\
\text { Sanitário }\end{array}$ \\
\hline Estrela do Norte & 8,7 & $10 / 13$ & $15 / 22$ & $\begin{array}{l}\text { Implantação de Aterro } \\
\text { Sanitário }\end{array}$ \\
\hline $\begin{array}{l}\text { Euclides da Cunha } \\
\text { Paulista }\end{array}$ & 7,1 & $8 / 13$ & $4 / 22$ & $\begin{array}{l}\text { Implantação de Aterro } \\
\text { Sanitário }\end{array}$ \\
\hline lepê & 5,1 & $9 / 13$ & $3 / 22$ & $\begin{array}{l}\text { Implantação de Aterro } \\
\text { Sanitário }\end{array}$ \\
\hline Indiana & 4,6 & $7 / 13$ & $5 / 22$ & $\begin{array}{l}\text { Implantação de Aterro } \\
\text { Sanitário }\end{array}$ \\
\hline Marabá Paulista & 7,1 & $7 / 13$ & $6 / 22$ & $\begin{array}{l}\text { Implantação de Aterro } \\
\text { Sanitário }\end{array}$ \\
\hline Martinópolis & 7,2 & $8 / 13$ & $8 / 22$ & $\begin{array}{l}\text { Implantação de Aterro } \\
\text { Sanitário }\end{array}$ \\
\hline $\begin{array}{l}\text { Mirante do } \\
\text { Paranapanema }\end{array}$ & 7,3 & $7 / 13$ & $8 / 22$ & $\begin{array}{l}\text { Implantação de Aterro } \\
\text { Sanitário }\end{array}$ \\
\hline Nantes & 9,5 & $6 / 13$ & $7 / 22$ & $\begin{array}{l}\text { Implantação de Aterro } \\
\text { Sanitário }\end{array}$ \\
\hline Narandiba & 7,2 & $9 / 13$ & $12 / 22$ & $\begin{array}{l}\text { Implantação de Aterro } \\
\text { Sanitário }\end{array}$ \\
\hline Pirapozinho & 2,8 & $1 / 13$ & $0 / 22$ & Encerramento da Área \\
\hline Presidente Bernardes & 9,0 & $3 / 13$ & $10 / 22$ & Encerramento da Área \\
\hline Presidente Epitácio & 7,4 & $9 / 13$ & $6 / 22$ & Encerramento da Área \\
\hline Presidente Venceslau & 8,4 & $10 / 13$ & $8 / 22$ & Reestruturação do Aterro \\
\hline Regente Feijó & 7,5 & $8 / 13$ & $6 / 22$ & Encerramento da Área \\
\hline Rosana & 7,2 & $10 / 13$ & $5 / 22$ & $\begin{array}{l}\text { Implantação de Aterro } \\
\text { Sanitário }\end{array}$ \\
\hline Sandovalina & 7,3 & $8 / 13$ & $11 / 22$ & $\begin{array}{l}\text { Implantação de Aterro } \\
\text { Sanitário }\end{array}$ \\
\hline Santo Anastácio & 7,1 & $8 / 13$ & $7 / 22$ & Encerramento da Área \\
\hline Taciba & 8,5 & $4 / 13$ & $3 / 22$ & Encerramento da Área \\
\hline Tarabai & 7,4 & $5 / 13$ & $2 / 22$ & $\begin{array}{l}\text { Implantação de Aterro } \\
\text { Sanitário }\end{array}$ \\
\hline Teodoro Sampaio & 7,5 & $9 / 13$ & $12 / 22$ & $\begin{array}{l}\text { Implantação de Aterro } \\
\text { Sanitário }\end{array}$ \\
\hline
\end{tabular}

* Referem-se ao total de parâmetros atendidos para cada um dos depósitos de resíduos sólidos regionais conforme a Tabela 1. 
Convém lembrar que existem casos específicos onde o aterro situa-se muito próximo aos núcleos populacionais, ou até mesmo dos recursos hídricos, infringindo os parâmetros elencados. Outro fator a ser observado diz respeito a questão de não existirem aterros na condição adequada conforme a Lei 12.305/10 (BRASIL. Congresso Nacional, 2010), ou seja, aterros sanitários. Por essa razão, mesmo que o município cumpra boa parte dos requisitos necessários, esses aterros ainda não possuem os critérios necessários para serem considerados como adequados.

Por último, recomenda-se que sejam implantados aterros sanitários nas áreas que possuam condições naturais favoráveis, adequando-se às normas vigentes. Em áreas que apresentam uma condição incompatível com os parâmetros mínimos é recomendável o encerramento de suas atividades e a recuperação ambiental local. O que foi observado nas vistorias ao longo dos últimos anos não foi uma melhoria, mas $\operatorname{sim}$ a tendência à piora. Em suma, o descaso com os depósitos de lixo somente impacta o meio ambiente regional.

\section{CONCLUSÃO}

O objetivo deste trabalho consistiu em apresentar os problemas observados durante as vistorias in situ, nos anos de 2013 e 2014, nos 22 aterros de resíduos sólidos localizados na 22a ${ }^{\mathrm{a}}$ Unidade de Gerenciamento de Recursos Hídricos do Pontal do Paranapanema. A hipótese estabelecida consistiu em que os aterros sanitários dessa bacia hidrográfica não se aparentam efetivamente como se tem divulgado nos resultados do estudo realizado pela CETESB. Os resultados das vistorias em campo possibilitam corroborar essa hipótese.

Constatou-se uma série de irregularidades em todos os 22 depósitos de resíduos sólidos visitados. Embora o órgão ambiental opte por atribui a designação de aterros, uma vasta parcela dos mesmos não possuem sequer as exigências conceituais mínimas para tal atribuição, refletindo as mesmas condições que os lixões a céu aberto. Diante dessa constatação, recomenda-se que as práticas de gerenciamento atentem-se para aquilo estipulada por Lei, ou seja, a implementação de aterros sanitários. Entretanto, as condições geotécnicas locais devem ser levadas em consideração, e, para isso, o conhecimento do meio físico assume papel primordial na adequação de áreas para destinação dos resíduos.

\section{REFERÊNCIAS}

BRASIL. Congresso Nacional. Política Nacional de Resíduos Sólidos. Lei n.o 12.305, de 2 de Agosto de 2010. Dispõe sobre seus princípios, objetivos e instrumentos. Diário Oficial da União, Brasília, DF. 
COMPANHIA DE TECNOLOGIA DE SANEAMENTO AMBIENTAL. Inventário estadual de resíduos sólidos domiciliares. São Paulo: CETESB, 2014.

FARIAS, F.S. Índice da qualidade de aterros de resíduos urbanos. 2002. Tese (Doutorado) - Universidade Federal do Rio de Janeiro, Rio de Janeiro - RJ.

GIORDANO, G.; FILHO, O. B.; CARVALHO, R. J. Processos físico-químicos para tratamento do chorume de aterros de resíduos sólidos urbanos. 1. ed. Rio de Janeiro. 2011. Coletânea em Saneamento Ambiental. Série Temática. Tecnologias Ambientais. Volume 4.

LOUREIRO, S. M. Índice de Qualidade no Sistema da Gestão Ambiental em Aterros de Resíduos Sólidos Urbanos - IQS. 2005. Dissertação (Mestrado) - Universidade Federal do Rio de Janeiro, Rio de Janeiro - RJ.

PASCHOALATO, C. F. P. R.; BLUNDI, C. E.; FERREIRA, J. F. Caracterização dos líquidos percolados gerados por disposição de lixo urbano. In: Congresso Interamericano de Engenharia Sanitária e Ambiental, 27. Porto Alegre (RS), 2000. Anais... ABES, Rio de Janeiro. CD-ROM, 2000.

SOUZA, G. Monitoramento de parâmetros qualitativos e quantitativos de líquidos percolados de aterros sanitários: estudo em piloto experimental. 2005. Dissertação (Mestrado) - Universidade Federal de Santa Catarina, Florianópolis - SC.

ZUQUETTE, L.V.; GANDOLFI, N. Problems and rules to select the landfill waste disposal sites Brazil. In: SYMPOSIUM INTERNATIONAL SUR LA GEOLOGIE URBAINE. Proceedings... Sfax, Tunisie, 1991. 